\title{
Antibacterial Potency Screening of the Crude Extracts of Adenanthera pavonina L.
}

\author{
Abdul Matin, W Islam*, O Ali Mandal \\ Institute of Biological Sciences, University of Rajshahi, Bangladesh
}

Copyright (C) 2015 by authors, all rights reserved. Authors agree that this article remains permanently open access under the terms of the Creative Commons Attribution License 4.0 International License

\begin{abstract}
The anitbacterial potency screening of the crude extracts of leaves, seed and stem wood of Adenanthera pavonina $\mathrm{L}$. were tasted against 15 Gram-positive and Gram-negative bacteria along with a standard antibiotic, Ciprofloxacin. The in vitro screening for antimicrobial potency was carried out by following the agar diffusion and micro broth dilution techniques. Among the fifteen bacterial strains tested the chloroform fraction of the seed extract showed promising antibacterial efficacy against Salmonella- $\beta$-haemolyticus, Serratia dysenteriae and Escherarichia coli. The susceptibility order of extracts were seed $>$ leaf $>$ stem. The MIC values of the chloroform seed extract were determined $256 \mu \mathrm{g} / \mathrm{ml}$ against $B$. cerus; 128 $\mu \mathrm{g} / \mathrm{ml}$ against $S .-\beta$-haemolyticus, $S$. dysenteriaeand 64 $\mu \mathrm{g} / \mathrm{ml}$ against Klebsiella sp. The MIC values of the chloroform extracts of stem wood were $128 \mu \mathrm{g} / \mathrm{ml}$ $S .-\beta$-haemolyticus; $64 \mu \mathrm{g} / \mathrm{ml}$ against B. megaterium, $S$. sonnei and $32 \mu \mathrm{g} / \mathrm{mlagainst} S$. typhi.
\end{abstract}

Keywords Adenanthera Pavonina, Extract, Antibacterial Screening, Disc Diffusion Assay, Zone of Inhibition, MIC

\section{Introduction}

The plants are the natural chemical factories that synthesize unmemorable compounds. The plants-derived compounds have been utilized by the human kind from time immemorial in different sectors of life, including public health and pest management. The test plant is native to Bangladesh and is easily available. They are well known for their medicinal values.

Adenanthera pavonina $\mathrm{L}$. is a deciduous, erect, unarmed tree $6-15 \mathrm{~m}$ high, distributed up to native to India, China, Malaysia and Africa. In Bangladesh it is occasionally grown under cultivation reported by Zarnowski et al. [1]. It is a monogenic plant in family Fabaceae and commonly known as Rakta chandan, Ranjana, Rakta kambal, Bead tree, Coral wood tree, Red sandalwood, etc. Tradinally, different parts of $A$. pavonina have been used for the treatment of different human disorders like chronic rheumatism, diarrhea, dysentery, antiseptic paste, pulmonary affections, chronic ophthalmia and reported to have properties such as antioxidant, antibacterial by Jayasinghe et al. [2]. There have also been reports on cytotoxicity of crude extract determined using the brine shrimp assay observed by Ajaiyeoba et al. [3]. The plants also contain alkaloid, octacosanol, saponin, stigmasterol, $\mathrm{HCN}$-glocoside, lignoceric acid and 2,4-di-OH-benzoic acid. Here we report a comparative potency of extracts obtained in different solvents from leaves, seed and stem wood of $A$. pavonina to inhibit Gram-positive and Gram-negative bacteria due to their random use in customary and traditional medicine to cure common ailments such as rheumatism, diarrhea, chronic ophthalmia etc.

\section{Materials and Methods}

Plant collection and identification: The plant specimen was collected from Botanical Garden, Rajshahi University Campus. Identification of voucher specimens was confirmed at the Taxonomical Section, Department of Botany, University of Rajshahi, Bangladesh.

Preparation of extract: The leaves, seeds and steam woods was cut into small pieces, dried in shade, stored in cotton bags and then finely powdered $(100 \mathrm{~g})$ separately with the help of a grinder. Each ground material was soaked in $500 \mathrm{~mL}$ petroleum ether, acetone, chloroform and methanol (BDH, pooleg England) separately for 24-72 $\mathrm{h}$ and filtered (Whatman No. 1). The filtered one was then allowed to vaporize in rotary evaporator until completely dried and kept in a refrigerator at $-20^{\circ} \mathrm{C}$ with proper labeling. Then dried extract $(100 \mathrm{mg}$ and $50 \mathrm{mg}$ ), for further study, was weighed and dissolved in $10 \mathrm{~mL}$ of respective solvents for dilution.

Antibacterial screening: Inhibitory activity of the extracts was performed by following the agar well diffusion method of Perez et al. [4]. Fifteen pathogenic bacteria (six gram-positive and nine gram-negative) were selected for the antibacterial test and were cultured at the Molecular Laboratory, Institute of Biological Sciences, Rajshahi 
University. The test extracts were dissolved in respective solvents in such a manner that the desired concentrations (50 and $200 \mu \mathrm{g} / \mathrm{disc}$ ) for application in the disc have been obtained. Standard antibiotic discs of Ciprofloxacin (30 $\mu \mathrm{g} /$ disc) was also used for comparison.

The six gram positive bacterial strains, viz., Staphylococcus aureus (ATCC-259233), Sercinia lutea (QL-166),Bacillus subtilis (QL-40),Bacillus megaterium (QL-38), Bacillus cereus (ATCC-14603) and Streptococcus- $\beta$-haemolyticus (ATCC-10389) and nine gram negative bacterial strains, viz., Salmonella typhi (ATCC-14028),Shigella dysenteriae (AL-35587), Escherichia coli (FPFC-1407), Shigella shiga (ATCC-26107), Shigella boydii (AL-17313), Shigella sonnei (AJ-8992), Proteus vulgaris, Klebsiella pneumoniae and Pseudomonus aeruginosa (ATCC-27853) were obtained from the mother stock of the Enteric Microbiology Laboratory, ICDDR,B Dhaka and the Molecular Biology Laboratory, Institute of Biological Sciences, University of Rajshahi, Bangladesh.

Antibacterial activity was determined as diameter of inhibition zone using disc diffusion method of Perez et al. [4]. Nutrient agar (NA) and Saboroud Dextrose agar (SDA) were distributed in sterilized petridishes. This was accomplished by placing $10 \mu 1$ of the extract on a small $(6 \mathrm{~mm})$ filter paper disc. This disc was placed on an agar growth medium containing a confluent lawn of microorganism. The concentration of the organism was also $10 \mu 1 /$ petridish. The absence of bacterial and fungal growth around the disc indicated that the plant extract contains antimicrobial properties against that particular organism.

Determination of Minimum Inhibitory Concentration (MIC): The serial dilution technique was followed using nutrient broth medium of Reiner [5] to determine the MIC values of the chloroform and methanol extracts against $B$. cerus, B. Megaterium, S. aureus, S. sonnei and S. dysenteriae. The selected extracts were taken into different vials in a fixed amount ( $2.048 \mathrm{mg})$, and then broth medium $(2 \mathrm{ml})$ was added to each of the vials and agitated well to make sample solution whose concentration become $1024 \mu \mathrm{g} / \mathrm{ml}$. The standard antibiotic Ciprofloxacin solution $512 \mu \mathrm{g} / \mathrm{ml}$ was used for comparison.

\section{Results and Discussion}

\section{Antibacterial Effect}

The anitbacterial activity of $A$. pavonina extractives collected in petroleum ether, acetone, chloroform and methanol of leaves, seed and stem wood were tested against 15 bacteria. A correlation was found between the antibacterial activity observed by agar disc diffusion assay and MIC determination.

The highest average zone of inhibition was found $25 \mathrm{~mm}$ and $22 \mathrm{~mm}$ against: $S$. $-\beta$-haemolyticus by chloroform fraction of seed extract and stem wood extract and also against methanol fraction of same bacteria (Table 2) when compared to the ciprofloxacin $33 \mathrm{~mm}$ in diameter against Proteus sp. of seed extract and S. typhi of stem wood extracts. Then moderate zone of inhibition were recorded respectively against gram positive and gram negative bacterial strains in both type of extraction either chloroform and methanol by seed, leaf and stem wood presented in Tables (1-3). The highest average zone of inhibition was found $24 \mathrm{~mm}$ against S. boydii by pet. Ether and acetone fraction of leaf extracts compared to the ciprofloxacin $33 \mathrm{~mm}$ in diameter against $S$. typhi and Proteus sp. of seed extract and leaf extracts respectively (Tables 1-2). Remaining of the lowest average zone inhibition activity was $6 \mathrm{~mm}$ against $S$. dysenteriae of leaf extract of chloroform fraction whereas the comparative study of ciproflozacin showed; $26 \mathrm{~mm}$ in diameter against gram positive bacteria $S$. aureus and $28 \mathrm{~mm}$ in diameter against gram negative bacteria $B$. cereus, Klebsiella sp.

Table 1. Antibacterial activity of the leaf extracts of A. pavonina and the standard Ciprofloxacin.

\begin{tabular}{|c|c|c|c|c|c|c|c|c|c|}
\hline Test organisms & \multicolumn{9}{|c|}{ Diameter of zone of inhibition (in $\mathrm{mm}$ ) each disc $=6 \mathrm{~mm}$} \\
\hline \multirow{2}{*}{$\mu \mathrm{g} / \mathrm{disc}$} & \multicolumn{2}{|c|}{ Chloroform extract } & \multicolumn{2}{|c|}{ Methanol extract } & \multicolumn{2}{|c|}{ Pet. Ether extract } & \multicolumn{2}{|c|}{ Acetone extract } & \multirow{2}{*}{$\begin{array}{c}\text { Ciprofloxacin } 30 \\
\mu \mathrm{g} / \mathrm{disc}\end{array}$} \\
\hline & 50 & 200 & 50 & 200 & 50 & 200 & 50 & 200 & \\
\hline \multicolumn{10}{|c|}{ Gram positive bacteria } \\
\hline S. aureus & 8 & 16 & - & - & - & - & - & - & 33 \\
\hline B. cereus & - & - & 9 & 20 & 9 & 19 & 10 & 20 & 28 \\
\hline B. megaterium & 9 & 15 & 10 & 22 & 10 & 21 & 12 & 24 & 31 \\
\hline B. subtilis & - & - & - & - & - & - & - & - & 30 \\
\hline S. lutea & - & - & - & - & - & - & - & - & 31 \\
\hline S.- $\beta$-haemolyticus & 10 & 20 & 8 & 17 & 11 & 23 & - & - & 30 \\
\hline \multicolumn{10}{|c|}{ Gram negative bacteria } \\
\hline S. typhi & 8 & 15 & 7 & 16 & - & - & - & - & 31 \\
\hline S. dysenteriae & 6 & 17 & - & - & 9 & 17 & 8 & 18 & 30 \\
\hline S. shiga & - & - & - & - & 8 & 18 & 9 & 20 & 31 \\
\hline S. sonnei & - & - & - & - & - & - & - & - & 30 \\
\hline S. boydii & - & - & - & - & 12 & 24 & 10 & 21 & 30 \\
\hline E. coli & - & - & - & - & - & - & - & - & 31 \\
\hline Klebsiella sp. & 8 & 18 & 6 & 14 & 9 & 19 & - & - & 28 \\
\hline P. aeruginosa & - & - & - & - & - & - & - & - & 30 \\
\hline Proteus sp. & - & - & - & - & - & - & - & - & 31 \\
\hline
\end{tabular}


Table 2. Antibacterial activity of the seed extracts of A. pavonina and the standard Ciprofloxacin.

\begin{tabular}{|c|c|c|c|c|c|c|c|c|c|}
\hline \multirow{3}{*}{$\begin{array}{c}\text { Test organisms } \\
\mu \mathrm{g} / \mathrm{disc}\end{array}$} & \multicolumn{9}{|c|}{ Diameter of zone of inhibition (in $\mathrm{mm}$ ) each disc $=6 \mathrm{~mm}$} \\
\hline & \multicolumn{2}{|c|}{ Chloroform extract } & \multicolumn{2}{|c|}{ Methanol extract } & \multicolumn{2}{|c|}{ Pet. Ether extract } & \multicolumn{2}{|c|}{ Acetone extract } & \multirow{2}{*}{$\begin{array}{c}\text { Ciprofloxacin } \\
30 \mu \mathrm{g} / \text { disc }\end{array}$} \\
\hline & 50 & 200 & 50 & 200 & 50 & 200 & 50 & 200 & \\
\hline \multicolumn{10}{|c|}{ Gram positive bacteria } \\
\hline S. aureus & - & - & - & - & - & - & - & - & 26 \\
\hline B. cereus & - & 14 & - & 18 & 11 & 21 & 7 & 16 & 28 \\
\hline B. megaterium & - & 15 & - & 16 & 10 & 20 & 6 & 15 & 30 \\
\hline B. subtilis & - & - & 10 & 20 & - & - & - & - & 32 \\
\hline S. lutea & - & - & - & - & 12 & 22 & 10 & 21 & 26 \\
\hline S.- $\beta$-haemolyticus & 12 & 25 & 10 & 21 & 9 & 18 & - & - & 32 \\
\hline \multicolumn{10}{|c|}{ Gram negative bacteria } \\
\hline S. typhi & - & - & - & - & 10 & 20 & - & - & 33 \\
\hline S. dysenteriae & 10 & 18 & - & - & 11 & 21 & 8 & 16 & 29 \\
\hline S. shiga & - & - & - & - & - & - & - & - & 30 \\
\hline S. sonnei & - & - & - & - & - & - & - & - & 30 \\
\hline S. boydii & - & - & - & - & 9 & 16 & 11 & 18 & 29 \\
\hline E. coli & - & 22 & - & - & - & - & - & - & 29 \\
\hline Klebsiella sp. & - & - & 9 & 16 & 12 & 20 & 10 & 19 & 31 \\
\hline P. aeruginosa & - & - & - & - & - & - & - & - & 31 \\
\hline Proteus sp. & - & - & - & - & - & - & - & - & 33 \\
\hline
\end{tabular}

Table 3.Antibacterial activity of the stem wood extracts of A. pavonina and the standard Ciprofloxacin.

\begin{tabular}{|c|c|c|c|c|c|c|c|c|c|}
\hline \multirow{3}{*}{$\begin{array}{c}\text { Test organisms } \\
\mu \mathrm{g} / \mathrm{disc}\end{array}$} & \multicolumn{9}{|c|}{ Diameter of zone of inhibition (in $\mathrm{mm}$ ) each disc $=6 \mathrm{~mm}$} \\
\hline & \multicolumn{2}{|c|}{ Chloroform extract } & \multicolumn{2}{|c|}{ Methanol extract } & \multicolumn{2}{|c|}{ Pet. Ether extract } & \multicolumn{2}{|c|}{ Acetone extract } & \multirow{2}{*}{$\begin{array}{l}\text { Ciprofloxacin } \\
30 \mu \mathrm{g} / \text { disc }\end{array}$} \\
\hline & 50 & 200 & 50 & 200 & 50 & 200 & 50 & 200 & \\
\hline \multicolumn{10}{|c|}{ Gram positive bacteria } \\
\hline S. aureus & - & - & - & - & - & - & 7 & 17 & 28 \\
\hline B. cereus & 9 & 20 & 6 & 15 & 9 & 20 & 6 & 15 & 28 \\
\hline B. megaterium & 8 & 20 & - & - & 8 & 20 & - & - & 30 \\
\hline B. subtilis & 7 & 18 & 5 & 14 & - & - & - & - & 30 \\
\hline S. lutea & - & - & - & - & - & - & - & - & 31 \\
\hline S.- $\beta$-haemolyticus & 10 & 22 & 7 & 17 & 10 & 23 & 7 & 16 & 33 \\
\hline \multicolumn{10}{|c|}{ Gram negative bacteria } \\
\hline S. typhi & 9 & 21 & 8 & 18 & - & - & - & - & 33 \\
\hline S. dysenteriae & 8 & 20 & - & - & 10 & 20 & 9 & 18 & 30 \\
\hline S. shiga & - & - & - & - & - & - & - & - & 30 \\
\hline S. sonnei & 9 & 21 & - & - & 8 & 20 & 6 & 14 & 31 \\
\hline S. boydii & - & - & 7 & 16 & - & - & - & - & 31 \\
\hline E. coli & - & - & - & - & - & - & 7 & 16 & 30 \\
\hline Klebsiella sp. & 8 & 20 & - & - & 8 & 16 & - & - & 28 \\
\hline P. aeruginosa & - & - & - & - & - & - & - & - & 30 \\
\hline Proteus sp. & - & - & - & - & - & - & - & - & 28 \\
\hline
\end{tabular}


Table 4. Minimum inhibitory concentrations of the chloroform extract of seed and stem wood of $A$. pavonina against pathogenic bacteria.

\begin{tabular}{|c|c|c|c|c|c|c|c|c|c|c|c|}
\hline \multirow{3}{*}{$\begin{array}{l}\text { Test } \\
\text { tube } \\
\text { No. }\end{array}$} & \multirow{3}{*}{$\begin{array}{c}\text { Nutrient } \\
\text { broth or } \\
\text { potatode } \\
\text { xtrose } \\
\text { broth } \\
\text { medium } \\
\text { added } \\
(\mathrm{ml})\end{array}$} & \multirow{3}{*}{$\begin{array}{l}\text { Diluted } \\
\text { solution } \\
\text { of } \\
\text { chlorof } \\
\text { orm } \\
\text { extract } \\
\text { from } \\
\text { root }(\mu \mathrm{g} \\
/ \mathrm{ml}) \\
\end{array}$} & \multirow{3}{*}{$\begin{array}{c}\text { Inoculu } \\
\text { ms } \\
\text { added } \\
(\mu 1)\end{array}$} & \multicolumn{4}{|c|}{ Seed extracts } & \multicolumn{4}{|c|}{ Stem wood extracts } \\
\hline & & & & $\begin{array}{c}\text { S. }-\beta-h \\
\text { aemoly } \\
\text { ticus }\end{array}$ & $\begin{array}{c}S . \\
\text { dysent } \\
\text { eriae }\end{array}$ & $\begin{array}{l}\text { Klebsi } \\
\text { ella sp. }\end{array}$ & $\begin{array}{c}B . \\
\text { cereus }\end{array}$ & $\begin{array}{c}\text { S.- } \beta \text {-haemolyti } \\
\text { cus }\end{array}$ & $\begin{array}{c}\text { S. } \\
\text { sonnei }\end{array}$ & $\begin{array}{c}S . \\
\text { typhi }\end{array}$ & $\begin{array}{c}B . \\
\text { megaterium }\end{array}$ \\
\hline & & & & & & & & & & & \\
\hline 1 & 1 & 512 & 10 & - & - & - & - & - & - & - & - \\
\hline 2 & 1 & 256 & 10 & - & - & - & - & - & - & - & - \\
\hline 3 & 1 & 128 & 10 & - & - & - & + & + & - & - & - \\
\hline 4 & 1 & 64 & 10 & + & - & + & + & + & + & - & + \\
\hline 5 & 1 & 32 & 10 & + & + & + & + & + & + & + & + \\
\hline 6 & 1 & 16 & 10 & + & + & + & + & + & + & + & + \\
\hline 7 & 1 & 8 & 10 & + & + & + & + & + & + & + & + \\
\hline 8 & 1 & 4 & 10 & + & + & + & + & + & + & + & + \\
\hline 9 & 1 & 2 & 10 & + & + & + & + & + & + & + & + \\
\hline 10 & 1 & 1 & 10 & + & + & + & + & + & + & + & + \\
\hline $\mathrm{Cm}$ & 1 & 0 & 0 & - & - & - & - & - & - & - & - \\
\hline $\mathrm{Cs}$ & 1 & 1024 & 0 & - & - & - & - & - & - & - & - \\
\hline $\mathrm{Ci}$ & 1 & 0 & 10 & + & + & + & + & + & + & + & + \\
\hline \multicolumn{4}{|c|}{ Results of MIC values $(\mu \mathrm{g} / \mathrm{ml})$} & 128 & 128 & 64 & 256 & 128 & 64 & 32 & 64 \\
\hline
\end{tabular}

\section{Minimum inhibitory concentrations (MICs) against test bacteria}

Only chloroform extracts of the seed and the stem wood were subjected to evaluate the minimum inhibition zones just depending on the intensity of activity (Table 4). The MIC value of the chloroform extract of the seed was $256 \mu \mathrm{g} / \mathrm{ml}$ against $B$. cereus, and $128 \mu \mathrm{g} / \mathrm{ml}$ against $S$. $\beta$-haemolyticus, S. dysenteriae and $64 \mu \mathrm{g} / \mathrm{ml}$ against Klebsiella sp. The MIC values of the chloroform extract of seed were $128 \mu \mathrm{g} / \mathrm{ml}$ against $S$.- $\beta$-haemolyticus, $S$. dysenteriae; $64 \mu \mathrm{g} / \mathrm{ml}$ against Klebsiella sp. and $256 \mu \mathrm{g} / \mathrm{ml}$ against $B$. cereus. The MIC values of the chloroform extract of stem wood were $128 \mu \mathrm{g} / \mathrm{ml}$ against $S$.- $\beta$-haemolyticus; $64 \mu \mathrm{g} / \mathrm{ml}$ against $B$. megaterium, $S$. sonnei and $32 \mu \mathrm{g} / \mathrm{ml}$ against $S$. typhi.

The chloroform and methanol extracts of seed and seed coats of $A$. pavonina especially at $200 \mu \mathrm{g} / \mathrm{disc}$ were very effective. When concentration of the extract was increased, the zone of inhibition was found to be increased. The MIC results indicated that the methanolic extract of the seed has the property of inhibiting bacterial growth even at low concentrations (64-128 $\mu \mathrm{g} / \mathrm{disc})$. This probably explains the use of the extract of this plant in traditional medicines against a number of infections. So more comprehensive works are very much to be solicited for their effective use, especially in medicine and agriculture.

The antibacterial study of $A$. pavonina extracts demonstrates that folk medicine can be as effective as modern medicine to combat pathogenic microorganisms. The millenarian use of these plants in folk medicine suggests that they represent an economic and safe alternative to treat infectious diseases, Girish and Satish [6]; Toama et al. [7].These findings support the traditional knowledge of local users and it is a preliminary, scientific, validation for the use of the plants for antibacterial activity to promote proper conservation and sustainable use of such plant resources, Li et al. [8], Eruteya and Odunfa [9]. Our previous studies have demonstrated that the reliable antibacterial potentiality of Solanum torvum and Clerodendrum infortunatum, Bari et al. [10], Waliullah et al. [11].

The present data on the antibacterial activity of the experimental plant are supported by a number of recent works. Kannur et al. [12] reported that the seed coat extracts of $C$. bonducwas more effective in controlling the inflammation. Cerqueira et al. [13] extracted, purified and characterized galactomannans from non-traditional sources. Four non-traditional galactomannans were isolated from the seeds of A. pavonina, C. pulcherrima, Gleditsia triacanthos and Sophora japonica. All the galactomannans from those plants in view of their importance, eg. in the demanding area of food industry. The finding also supports the antibacterial activity against $E$. coli, B. subtilis, $P$. aeruginosa and $S$. aureus and inhibitory effect on glucoamylase of ethanolic extracts isolated at different temperatures from seeds of $S$. cumini investigated in vitro, Gangadhar A. Meshram et al. [14]. Thus, we believe that $A$. pavonina will be a possible source for new antibacterial substances against important pathogens of medically and veterinary importance.

The findings evidently appear promising antibacterial 
properties of $A$. pavonina against antagonistic pathogens. Leaf possess quite potent activity than root and stem specially root extract $>$ leaf extract $>$ stem extract. This study serves as basis for further research to lead compounds to be isolated so that may be as a template for the implications of these results for bioactivity and drug discovery potential of herbal products are discussed.

\section{Acknowledgements}

Institute of Biological Sciences, University of Rajshahi has provided the laboratory facility and Ministry of Science and Technology, Government of the People's Republic of Bangladesh for financial support.

\section{REFERENCES}

[1] Zarnowski, R, A. Jaromin, M. Certik, T. Czabany, J. Fontaine, T. Jakubik, M. C. M. Iqbal, A. Grandmougin-Ferjiani, A. Kozulbek and S. J. Pietr 2004. The oil of Adenanthera pavonina L. seeds and its emulsions. Z. Naturforsch 59: $321-326$

[2] Jayasinghe, P. K. I. D. E., B. M. R. Bandara, E. W. M. A. Ekanayaka and V. Thevanesam 2006. Screening for antimicrobial activity of Acronychia pedunculata (Madatiya) against bacteria causing skin and wound infections in humans. Proc. Peradeniya University Research Sessions, Sri Lanka 11:105

[3] Ajaiyeoba, E. O., O. O. Abiodium, M. O. Falade, N. O. Ogbole, J. S. Ashidi, C. T. Happi and D. O. Akinboye 2006. In vitro cytotoxicity studies of 20 plants used in Nigerian antimalarial ethnomedicine. Phytomed 13: 295-298

[4] Perez, C., M. Paul and P. Bazerque 1990. Antibiotic assay by the agar-well diffusion method. Acta. Biol. Med. Exp. 15: $113-115$

[5] Reiner, R. 1982. Antibiotics: An introduction F. Hoffmann -La
Roche and Company Ltd. Switzerland, p. 70- 71

[6] Girish, H. V. and S. Satish 2008. Antibacterial activity of important medicinal plants on human pathogenic bacteria, Comparative Analysis. World J Appl. Sci. 5: 267-271

[7] Toama, M. A., T. S. El-Alfy and H. M. El- Fatatry1974. Antimicrobial activity of the volatile oil of Nigella sativa Linneaus seeds. Antimicrobial Agents and Chemotherapy 6: 225-226.

[8] Li, X. Z., D. M. Livermore and H. Nikaido 1994. Role of efflux pump(s) in intrinsic resistance of Pseudomonasaerugi nosa: resistance to tetracycline chloramphenicol and norfloxacin. Antimicrobial Agents and Chemotherapy 38: 1732-1741

[9] Eruteya, O. C. and S. A. Odunfa2009. Antimicrobial properties of three spices used in the preparation of soya condiment against organisms isolated from formulated samples and individual ingredients. Afr. J. Biotechnol. 8: 2316-2320

[10] Bari, M. A., W. Islam, A. R. Khan and Abul Mandal 2010. Antibacterial and antifungal activity of Solanum torvum (Solanaceae). Int. J. Agric. Biol. 12: 386-390

[11] Waliullah, T. M., A. M. Yeasmin, A. Ashraful, W. Islam and H. Parvez 2014. Antimicrobial potency screening of Clerodendrum infortunatum Linn. Int. Res. J. Pharm. 5 (2): $57-61$

[12] Kannur, D. M., M. P. Paranjpe, L. V. Sonavane, P. P. Dongre and K. R. Khandelwal 2012. Evaluation of Caesalpinia bonduc seed coat extract for anti-inflammatory and analgesic activity. J. Advanced Pharmaceutical Technol. Res. 3:171-175.

[13] Cerqueira, M. A., A. C. Pinheiro, W. S. Bartolomeu, Souza, M. P. Alvaro, Lima, Clara Ribeiro, C Miranda, J. A. Teixeira, R. A. Moreira, M. A. Coimbra, M. P. Goncalves and A. A. Vicente 2009. Extraction, purification and characterization of galactomannans from non-traditional sources. Elsevier. Carbohydrate Polymers 75 : 408-414.

[14] Meshram G. A., S. Sunil, Yadav, S. Dattatraya, P. Bhavana and S. Deepak 2011. Antibacterial and effect of ethanolic extracts of Syzgium cumini seeds powder on Glucoamylase invitro. J. Phar. Sci. \& Res. 3: 1732-1741. 